\title{
A retrospective evaluation of the pulmonary function tests and quality of life assessment surveys of emphysema patients subject to coil treatment
}

\author{
Erhan UĞURLU ${ }^{1}$ (ID) \\ Nazlı ÇETiN ${ }^{\mathbf{1}}$ (ID) \\ Nilüfer YiĞiT ${ }^{1}$ (ID) \\ Ümit AYDOĞMUŞ²(ID) \\ ilknur Hatice \\ AKBUDAK $^{3}$ (ID) \\ Hande ŞENOL ${ }^{4}(I D)$ \\ Fikri Selçuk ŞiMŞEK ${ }^{5}(I D)$ \\ Göksel ALTINIŞIK ${ }^{\mathbf{1}}(\mathrm{ID})$
}

\footnotetext{
${ }^{1}$ Department of Chest Diseases, Pamukkale University School of Medicine, Denizli, Turkey

${ }^{1}$ Pamukkale Üniversitesi Tıp Fakültesi, Göğüs Hastalıkları Anabilim Dalı, Denizli, Türkiye

2 Department of Thoracic Surgery, Pamukkale University School of Medicine, Denizli, Turkey

2 Pamukkale Üniversitesi Tıp Fakültesi, Göğüs Cerrahisi Anabilim Dalı, Denizli, Türkiye

${ }^{3}$ Department of Anesthesia and Reanimation Pamukkale University School of Medicine, Denizli, Turkey

3 Pamukkale Üniversitesi Tıp Fakültesi, Anestezi ve Reanimasyon Anabilim Dalı, Denizli, Türkiye

${ }^{4}$ Department of Biostatistics, Pamukkale University School of Medicine, Denizli, Turkey

4 Pamukkale Üniversitesi Tıp Fakültesi, Biyoistatistik Anabilim Dalı, Denizli, Türkiye

${ }^{5}$ Department of Nuclear Medicine, Pamukkale University School of Medicine, Denizli, Turkey

${ }^{5}$ Pamukkale Üniversitesi Tıp Fakültesi, Nükleer Tıp Anabilim Dalı, Denizli, Türkiye
}

Cite this article as: Uğurlu E, Çetin N, Yiğit N, Aydoğmuş $\ddot{U}$, Akbudak $i \mathrm{H}$, Senol $\mathrm{H}$, et al. A retrospective evaluation of the pulmonary function tests and quality of life assessment surveys of emphysema patients subject to coil treatment. Tuberk Toraks 2020;68(4):399-406.

\section{Dr. Ümit AYDOĞMUŞ}

Pamukkale Üniversitesi Tıp Fakültesi,

Gögüs Cerrahisi Anabilim Dalı,

DENIZLI - TÜRKIYE

e-mail: mdaydogmus@yahoo.com

CCopyright 2020 by Tuberculosis and Thorax.

Available on-line at www.tuberktoraks.org.com

\section{ABSTRACT}

A retrospective evaluation of the pulmonary function tests and quality of life assessment surveys of emphysema patients subject to coil treatment

Introduction: Bronchoscopic volume reduction treatments are among the important alternatives for selected emphysema patients with a dyspneic course despite optimal medical treatment. Our aim was to carry out a retrospective scan of the data for COPD patients subject to coil treatment at our center for assessing whether coil procedure has an impact on the respiratory symptom and pulmonary function tests in COPD patients.

Materials and Methods: The data of 41 patients with severe emphysema and treated with coils between 2017-2020 were evaluated retrospectively. Cardiopulmonary rehabilitation programs were completed for all patients 
prior to the procedure and they were assessed with pulmonary function test (PFT), diffusing capacity for carbonmonoxide test (DLCO), body plethysmography, 6-minute walk test, ventilation/perfusion scintigraphy, St. George's Respiratory Questionnaire (SGRQ). Data acquired prior to the procedure and $3^{\text {rd }}$ month control data after the procedure were recorded and SGRQ was applied via face-to-face interviews during the controls by doctors working on Pulmonary Diseases as was the case before the procedure.

Results: SGRQ questionnaires of 32 patients were evaluated. Statistically significant changes were observed after the procedure in symptom, activity, impact score and total score which were calculated prior to the procedure. Pre and post procedure FEV ${ }_{1}$ FVC, $\mathrm{FEV}_{1} / F V C$, PEF, FEF $25 / 75$ parameters were used for the comparison made via SFT. Statistically significant changes were observed in $F E V_{1}, F V C, F E F_{25 / 75}$ when the pre and post-procedure SFT parameters of the 32 patients included in the study were compared.

Conclusion: A statistically significant improvement was observed in the PFT parameters and quality of life questionnaires following the coil procedure which is a bronchoscopic volume reduction procedure.

Key words: D-Coil; emphysema; lung volume reduction; bronchoscopic volume reduction; SGRQ (St. George's Respiratory Questionnaire)

ÖZ

Coil tedavisi yapılmış olan amfizem hastalarının solunum fonksiyon testlerinin ve yaşam kalitesi değerlendirme anketlerinin retrospektif olarak incelenmesi

Giriş: Optimal medikal tedaviye rağmen dispneik seyreden seçilmiş amfizem hastalarında bronkoskopik volüm küçültme tedavileri önemli bir alternatiftir. Merkezimizde coil işlemi yapılan KOAH'lı hastaların geriye dönük takip verilerini tarayarak, coil işleminin $K O A H^{\prime} l ı$ hastalarda solunumsal semptom ve solunum fonksiyon testlerine etkisi olup olmadı ̌̆ını değerlendirmeyi amaçladık.

Materyal ve Metod: 2017-2020 yılları arasında şiddetli amfizemi olan, coillerle tedavi edilen 41 hastanın verileri retrospektif olarak değerlendirildi. İslem öncesi bütün hastaların kardiyopulmoner rehabilitasyon programları tamamlanmış, hastalar solunum fonksiyon testi (SFT), karbonmonoksit difüzyon testi (DLCO), vücut pletismografisi (body box), 6 dakika yürüme testi, ventilasyon/perfüzyon sintigrafisi, St. George Solunum Anketi (St. George's Respiratory Questionnaire, SGRQ) ile değerlendirilmiştir. İşlem öncesi ve işlem sonrası 3. ay kontrol verileri kaydedilmiş, işlem öncesi olduğu gibi kontrollerde de SGRQ anketi Gögüs Hastalıkları'nda çalışmakta olan doktorlar tarafından yüz yüze görüşülerek yapılmışır.

Bulgular: Toplam 32 hastanın SGRQ anketleri değerlendirildi. işlem öncesi hesaplanan semptom, aktivite, etki (impact) skoru ve toplam skorda işlem sonrası istatistiksel olarak anlamlı değişiklik gözlendi. SFT ile yapılan karşılaştırmada işlem öncesi ve sonrası FEV ${ }^{\prime}$ FVC, FEV $/ F V C, P E F, F E F_{25 / 75}$ parametreleri kullanıldı. Çalışmaya dahil edilen 32 hastanın işlem öncesi ve sonrası SFT parametreleri karşılaştırıldığında $F E V_{1}, F V C, F E F_{25 / 75}$ 'te istatistiksel olarak anlamlı değişiklik gözlendi.

Sonuç: Bronkoskopik volüm küçültücü bir işlem olan coil işleminin sonrasında solunum fonksiyon parametrelerinde ve yaşam kalitesi anketlerinde anlamlı bir düzelme olduğu saptanmıştır.

Anahtar kelimeler: Coil; amfizem; akciğer volüm küçültme; bronkoskopik volüm küçültme; SGRQ (St. George's Respiratory Questionnaire)

\section{INTRODUCTION}

Chronic obstructive pulmonary disease (COPD) is a widespread, preventable and treatable disease characterized by respiratory symptoms and permanent air flow restriction, related generally to severe exposure to harmful particles or gases and/or alveolar anomalies (1). Emphysema, an important component of COPD, is characterized by chronic inflammatory structural changes and permanent parenchymal damage in the lungs. This leads to dynamic hyperinflation, elastic recoil loss, air trapping resulting in reduced exercise capacity, shortness of breath, and an increased risk for mortality (2).

Quitting smoking, bronchodilator treatments, pulmonary rehabilitation, oxygen support, immunization programs, and required nutritional support are among the primary treatment options for COPD (3). However, the benefits of all these treatment options are limited in patients whose COPD is accompanied by emphysema since the actual pathology in emphysema is hyperinflation due to elastic-tissue damage. Bronchoscopic lung volume reduction treatments are among the important alternatives for selected emphysema patients with a dyspneic course despite optimal medical treatment (1). Several studies have reported that lung volume reduction procedures increase lung and respiratory muscle function, exercise performance, quality of life and survival in COPD patients with emphysema selected in accordance with criteria and that better clinical and functional results are attained particularly in patients with upper lobe predominant emphysema and those with low exercise capacity (4).

Lung parenchyma with abnormal elastic recoil can be contracted, thereby reducing the volume via smart-coil treatment, which is one of the volume 
reduction procedures (5). A literature survey showed that, although there are studies reporting recovery following coil treatment in COPD patients based on the 6-minute walk test, pulmonary-function test (PFT) parameters, and dyspnea assessment scales, the number of related studies remains limited in our country (6).

Our aim was to conduct a retrospective scan of the data for COPD patients subjected to coil treatment at our center in order to assess whether the coil procedure has an impact on the respiratory symptom and pulmonary function tests in patient with COPD.

\section{MATERIALS and METHODS}

\section{Patient Selection}

A total of 41 patients were included in the study who underwent the coil procedure and were monitored at our Pulmonary Diseases clinic; all had been diag- nosed with stage 3 or stage 4 COPD based on the Global Initiative for Chronic Obstructive Lung Disease (GOLD) diagnostic criteria (1), with emphysema detected by high-resolution computerized tomography. They were considered eligible for coil treatment and underwent the procedure during October 2017 and February 2020. In all, 32 patients were included in the study because 1 patient was re-coil, 2 patients died during follow-up (myocardial infarction, pneumonitis), and 6 patients did not come for the follow-up. Figure 1 presents a flow diagram of subjects included in this analysis. Table 1 presents the inclusion and exclusion criteria for the patient samples (4).

Cardiopulmonary rehabilitation programs were completed for all patients prior to the procedure and they were assessed with PFT, diffusing capacity for carbonmonoxide test (DLCO), body plethysmography, the 6-minute walk test, ventilation/perfusion scintig-

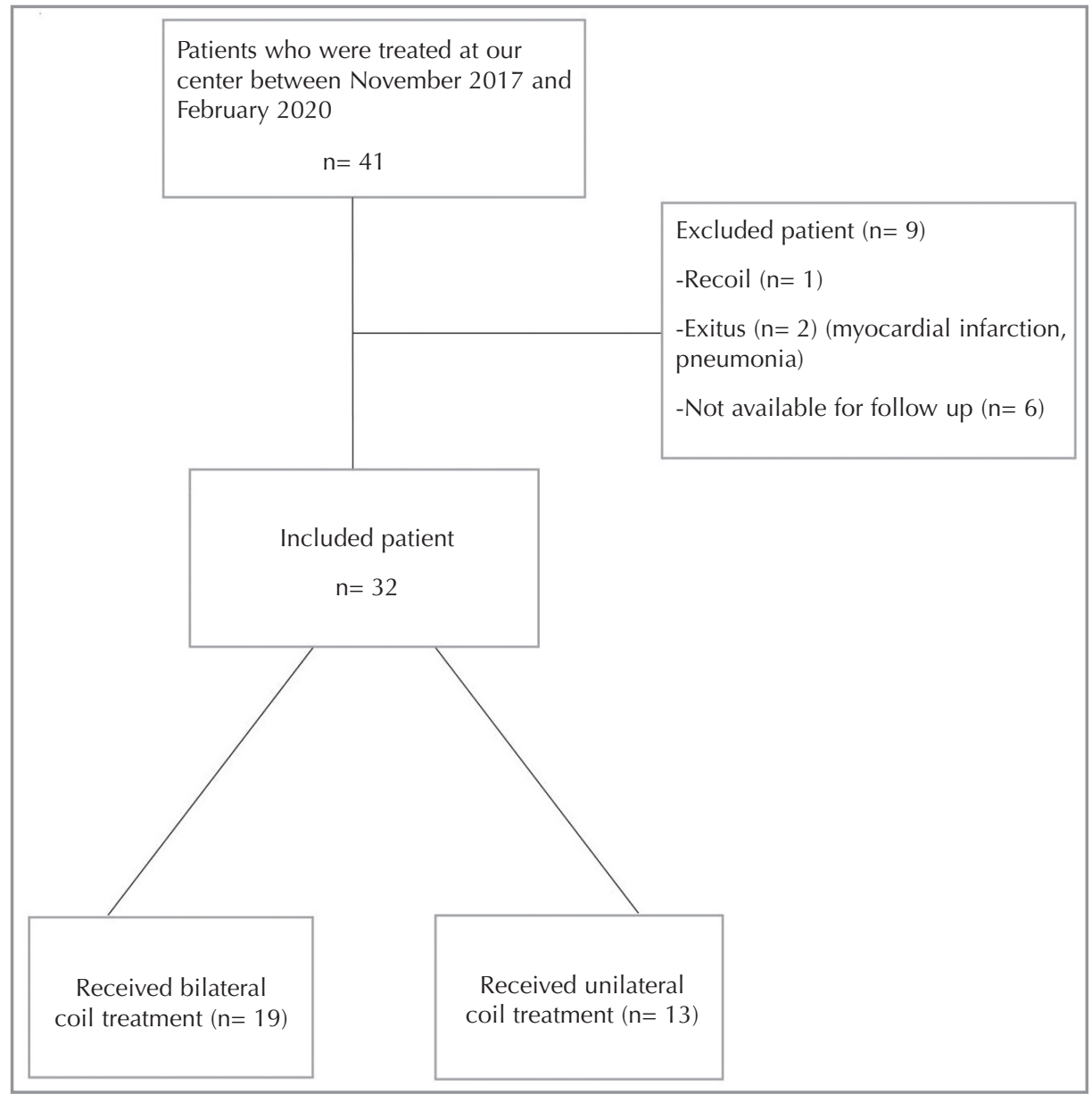

Figure 1. Flow diagram. 
Table 1. Patient inclusion and exclusion criteria

\section{Inclusion Criteria}

- Patients undergoing optimal medical treatment (quitting smoking maximum pharmacological treatment, pulmonary rehabilitation)

- GOLD Stage 3 or 4

- $\quad$ CAT score $\geq 10, \mathrm{mMRC} \geq 2$

- $\mathrm{FEV}_{1} 20-45 \%$

- $\mathrm{RV}$ expected $\geq \% 175$ or $\mathrm{RV} / \mathrm{TLC} \geq \% 58$

- 6-minute walk test $100-500 \mathrm{~m}$

\section{Exclusion Criteria}

- Severe PHT (sPAP >50 mmHg in ECO)

- Clinically severe bronchiectasis

- Suspected pulmonary module

- Diagnosed lung cancer or suspicion

- Interstitial fibrosis

- Severe tracheobronchomalacia

* GOLD: Global initiative for chronic obstructive lung disease; CAT: COPD assessment test; mMRC: Modified medical research council dyspnea scale; $\mathrm{FEV}_{1}$ : Forced expiratory volume in first second; RV: Residual volume; TLC: Total lung capacity; PHT: Pulmonary hypertension; sPAP: Systolic pulmonary arterial pressure; ECO: Echocardiography.

raphy, and St. George's Respiratory Questionnaire (SGRQ). The included PFT were as forced expiratory volume in the first second $\left(\mathrm{FEV}_{1}\right)$, forced vital capacity $(\mathrm{FVC})$, forced expiratory flow $25-75 \%\left(\mathrm{FEF}_{25-75}\right)$, peak expiratory flow (PEF), residual volume (RV), and total lung capacity (TLC). Data were collected prior to the procedure and again as third month control data after the procedure was recorded, and SGRQ was applied via face-to-face interviews during the controls by doctors treating pulmonary diseases as was the case before the procedure.

\section{Procedure}

Coil (PneumRx, Inc., Mountain View, Calif., USA) application:

The procedure was conducted under general anesthesia at the surgery department and aided by fluoroscopy. First, the airway in the selected segment is determined bronchoscopically, and its length is measured using a guide wire. A coil of suitable length (generally $100 \mathrm{~mm}, 125 \mathrm{~mm}$ or $150 \mathrm{~mm}$ ) is then placed on the targeted segment using a carrier catheter and takes on the shape of a coil. The airway contracts as the coil pulls on the lobe, and the lungs collapse and shrink. The targeted lobe is systematically treated with 10-14 coils, on average. While a single lobe is treated initially, the other targeted lobe in the opposite lung is treated 4-8 weeks later (4). A postero-anterior chest $x$-ray of the patient with the bilateral coil procedure is shown in Figure 2.

\section{Tools of Measurement}

- Pulmonary function test

- Diffusing capacity for carbon monoxide test

- Body plethysmography

- 6-minute walk test

\section{- Ventilation/perfusion scintigraphy}

- SGRQ: A specific questionnaire for respiratory diseases (7), SGRQ examines 50 factors of patients in three classifications: symptoms (8 items), activities (16 items), and effects of the disease (26 items). The response has an empirical weight in all items. Respiratory disorder in the patient, along with cough, phlegm, wheezing, and the level of shortness of breath, are examined when observing the symptoms. The activity score is related to physical activities that may lead to shortness of breath or those that are limited by shortness of breath, whereas the impact score comprises factors such as profession, occupation, managing one's health, panic, medication and its side effects, and discomfort

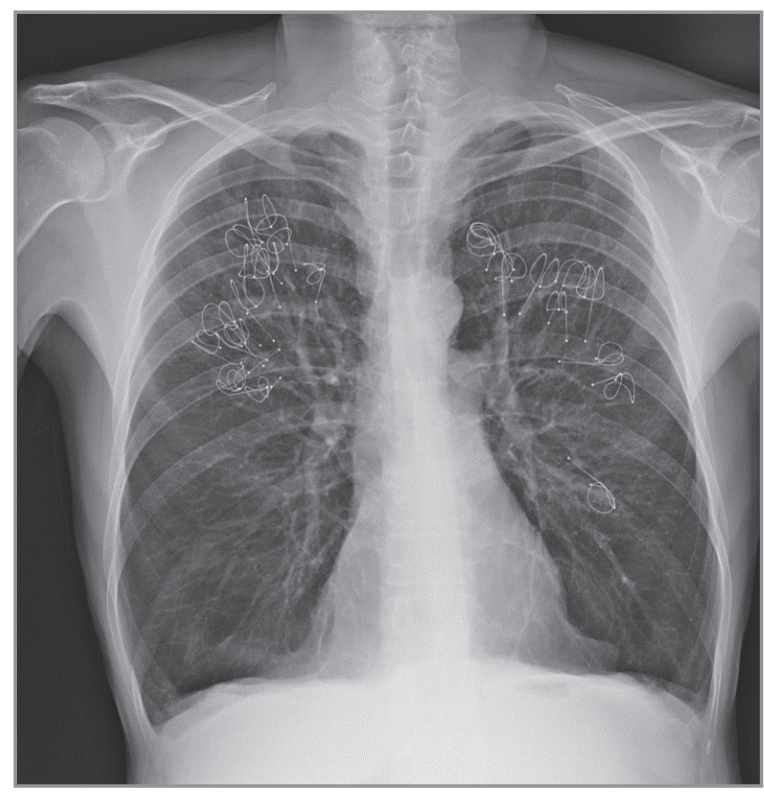

Figure 2. Postero-anterior chest X-ray of the patient after bilateral coil procedure. 
during daily activities of living. The three sections of the questionnaire are scored separately, after which the total score is calculated. The scores range from 0-100, with zero indicating normal function and 100 indicating the most severe symptoms. A four-point change in SGRQ due to treatment is considered statistically significant (8).

\section{Statistical Evaluation}

All statistical analyses were performed using SPSS 25.0 software (IBM SPSS Statistics 25 (Armonk, NY: IBM Corp.). Continuous data were reported as mean \pm standard deviation, whereas the categorical variables were presented in numbers and percentages. The Shapiro-Wilk test was used for testing normality. Regarding pairwise comparisons, paired samples t-test was used if the parametric test conditions were satisfied and Wilcoxon signed rank test if not. A p value $<0.05$ was considered statistically significant.

\section{RESULTS}

All 32 patients included in the study were male and, the mean age was 66.13. Comorbidities were benign prostatic hyperplasia in 10 patients $(31.25 \%)$, hypertension in 8 patients $(25 \%)$, cardiovascular disease in 7 patients $(21.87 \%)$, and diabetes in 4 patients $(12.5 \%)$, respectively. Table 2 presents the sociodemographic data for the patients included in the study.

SGRQ was used to assess 16 patients following unilateral coil procedure for control data, and 16 patients were subjected to the control questionnaire following the bilateral coil procedure, for a total of 32 patients. Statistically significant changes were observed following the procedure, and these were assessed by symptom, activity, impact score, and total score, which were also calculated prior to the procedure (Table 3 ).

Pre- and post- procedure $\mathrm{FEV}_{1}, \mathrm{FVC}, \mathrm{FEV}_{1} / \mathrm{FVC}, \mathrm{PEF}$, $\mathrm{FEF}_{25-75}$ parameters were used for the comparison

\section{Table 2. Sociodemographic characteristics and some clinical parameters}

\begin{tabular}{|c|c|c|}
\hline & Number (n) & Percentage (\%) \\
\hline \multicolumn{3}{|l|}{ Gender } \\
\hline Female & 0 & 0 \\
\hline Male & 32 & 100 \\
\hline \multicolumn{3}{|l|}{ Comorbidities } \\
\hline Benign prostatic hyperplasia & 10 & 31.25 \\
\hline Hypertension & 8 & 25 \\
\hline Cardiovascular disease & 7 & 21.87 \\
\hline Diabetes & 4 & 12.5 \\
\hline \multicolumn{3}{|l|}{ Procedure } \\
\hline Unilateral & 13 & 40.62 \\
\hline Bilateral & 19 & 59.38 \\
\hline \multicolumn{3}{|l|}{ Emphysema distribution } \\
\hline Homogeneous & 14 & 43.75 \\
\hline Heterogeneous & 18 & 56.25 \\
\hline \multicolumn{3}{|l|}{ GOLD spirometric stage } \\
\hline Stage 3 & 13 & 40.62 \\
\hline Stage 4 & 19 & 59.38 \\
\hline \multicolumn{3}{|l|}{ LTOT use } \\
\hline Yes & 9 & 28.12 \\
\hline \multirow[t]{2}{*}{ No } & 23 & 71.88 \\
\hline & Mean \pm SD & Median (min-max) \\
\hline Age & $66.13 \pm 6.47$ & $67.5(49-76)$ \\
\hline Used coil (qty.) & $15.44 \pm 5.41$ & $16(6-24)$ \\
\hline 6 MWT & $256.52 \pm 128.18$ & $210(100-495)$ \\
\hline
\end{tabular}


Table 3. St. George respiratory questionnaire (SGRQ) comparison

\begin{tabular}{|c|c|c|c|}
\hline$n=32$ & $\begin{array}{l}\text { Before the procedure } \\
\quad(\text { Mean } \pm \text { SD) }\end{array}$ & $\begin{array}{l}\text { After the procedure } \\
\quad(\text { Mean } \pm \text { SD })\end{array}$ & p \\
\hline Symptom score & $68.15 \pm 19.47$ & $58.27 \pm 17.24$ & $0.007 \alpha$ \\
\hline Activity score & $83.59 \pm 17.67$ & $71.22 \pm 19.52$ & $0.001 \beta$ \\
\hline Impact score & $62.74 \pm 22.28$ & $46.23 \pm 19.54$ & $0.0001 \alpha$ \\
\hline Total score & $70.09 \pm 18.26$ & $55.97 \pm 15.75$ & $0.0001 \alpha$ \\
\hline
\end{tabular}

Table 4. Pulmonary function test (PFT) comparison

\begin{tabular}{|c|c|c|c|}
\hline$n=32$ & $\begin{array}{l}\text { Before the procedure } \\
\quad(\text { Mean } \pm \text { SD) }\end{array}$ & $\begin{array}{l}\text { After the procedure } \\
\quad(\text { Mean } \pm \text { SD) }\end{array}$ & $\mathbf{p}$ \\
\hline FVC & $54.47 \pm 14.19$ & $61.27 \pm 15.03$ & $0.002 \alpha$ \\
\hline $\mathrm{FEV}_{1}$ & $29.12 \pm 9.57$ & $33.96 \pm 12.44$ & $0.001 \beta$ \\
\hline $\mathrm{FEV}_{1} / \mathrm{FVC}$ & $42.27 \pm 8.94$ & $42.42 \pm 7.9$ & $0.355 \beta$ \\
\hline PEF & $32.12 \pm 10.1$ & $42.42 \pm 7.9$ & $0.798 \alpha$ \\
\hline $\mathrm{FEF}_{25-75}$ & $11.28 \pm 3.83$ & $13.06 \pm 5.13$ & $0.007 \alpha$ \\
\hline
\end{tabular}

made with PFT. Statistically significant changes were observed in $\mathrm{FEV}_{1}, \mathrm{FVC}, \mathrm{FEF}_{25-75}$ when the pre- and post-procedure PFT parameters of the 32 patients included in the study were compared (Table 4).

Ventilation/perfusion scintigraphy scans could be obtained for only 11 patients subject to bilateral coil procedure. A statistically significant difference could not be observed when the pre- and post-procedure data were compared.

Major shortcomings were observed, especially in the control data on DLCO, body plethysmography, and the 6-minute walk test due to the diagnosis of advanced COPD in this patient population. In addition, the number of patients was not sufficient for assessment $(\mathrm{n}<10)$.

One patient developed a pneumothorax as a complication following the procedure, after which the patient returned to normal with tube drainage. Two patients died in the first month post-procedure, one due to myocardial infarction and one due to pneumonitis.

\section{DISCUSSION}

A positive and statistically significant change was determined in our study in all items of the volumeaire when the SGRQ results were compared before and after the coil procedure. Statistically significant changes were observed in the PFT parameters of $\mathrm{FVC}, \mathrm{FEV}_{1}$ and $\mathrm{FEF}_{25-75}$ before and after the procedure. The findings other than those for $\mathrm{FEF}_{25-75}$ were in accordance with the literature $(2,3,9)$. Based on our literature survey, there are no studies that examine the $\mathrm{FEF}_{25-75}$ parameter. Studies have generally focused on PFT parameters of FVC, FEV 1 , RV, TLC. Because the real problem in emphysema is hyperinflation, there is an increase in RV that reduces thoracic-wall compliance, thereby making it more difficult to breathe (10). Improvements are expected primarily in RV, as well as in other volumes and capacities after the coil procedure. Hence, these parameters were examined in these studies; however, peripheral airways are among the first areas affected by COPD, and $\mathrm{FEF}_{25-75}$ is one of the parameters that best presents the changes in peripheral airways (11). Since elastic recoil is reduced in emphysema, alveoli and small air-ways collapse during expiration and $\mathrm{FEF}_{25}$ 75 is low; thus an increase is expected in $\mathrm{FEF}_{25-75}$ since elastic recoil improves following the coil procedure.

In our study, the effects of coil therapy on respiratory function tests and the SGRQ in the short term were examined. A future research aim is to study the longterm effects and surveillance of these patients in the 
future. As a matter of fact, according to the results of the RESET study where the 5-year surveillance of coil therapy was examined, those who were eligible for coils were found to have improved in terms of surveillance compared to those who received standard care (12).

To the best of our knowledge, the number of studies on the coil procedure is limited in our country (1319). Similar findings related to PFT were determined when these studies were compared with the findings of the present study. The SGRQ was used only in the study by Gulsen (18). Even though the SGRQ findings were similar in our results, this study focused only on the total score when evaluating the SGRQ findings, whereas the symptom scores, activity scores, and impacts of the disease were evaluated separately in our study and all determined to be statistically significant. In the study conducted by Franke et al., significant changes were found in all three parameters in the pre-coil and post-coil comparison, similar to our study (20). Significant changes were found in the SGRQ in the study in which Fellrath et al. shared the results of assessment 6 months after coil treatment in patients with severe emphysema (21). In the study conducted by Bostancı et al., SGRQ was not included, but the Medical Research Council scale and Chronic Obstructive Pulmonary Disease assessment test were, and significant changes were observed after coil treatment (14). In the same study, a significant decrease was found in depression and anxiety scores after coil treatment.

No statistically significant change could be observed in either ventilation or perfusion when the targeted lobes (subjected to the lung volume reduction procedure) were evaluated during the ventilation/perfusion scintigraphy scans before and after the procedure in our study. It is expected that, after the volume reduction procedure, perfusion and ventilation will decrease in the lobe subjected to volume reduction, which will be directed to the other lobes (22). The number of studies on this topic is limited in the literature, and endobronchial valves have been used in all these studies as the volume reducer instead of the coil; in addition, perfusion and ventilation also decreased in the targeted lobe (23-25). Valves are of importance for obtaining these results, which are indicated in GOLD 2020 as proven among the bronchoscopic lung volume reduction procedures as an older procedure that has been the focus of a greater number of studies (1). As far as we know, the coil procedure has been used for volume reduction in only one study in which perfusion scintigraphy scans were taken before and after the procedure with no statistically significant change observed between the two (19).

A lack of control measurements in the patients after the procedure is the most important limitation of our study. There are no post-procedure control data, especially for body plethysmography, DLCO, and the 6 -minute walk test. The primary reason for this is that all patients are stage 4 advanced COPD patients. As part of the polyclinic notes, it was noted that they are in another hospital in regard to control or inflammation, or they are unable to come for control due to socioeconomic reasons, or that they have been unable to adapt to these tests, which require intensive physical effort.

In conclusion, a statistically significant improvement was observed in the PFT parameters and quality of life questionnaires following the coil procedure, which is a bronchoscopic lung volume reduction procedure.

Ethical Committee Approval: The approval for this study was obtained from Pamukkale University Ethical Committee (Decision no: 5 Date: 03.03.2020).

\section{CONFLICT of INTEREST}

The authors of this study declare that they have no conflict of interest.

\section{AUTHORSHIP CONTRIBUTIONS}

Concept/Design: EU

Analysis/Interpretation: $\mathrm{EU}, \mathrm{NC}, \mathrm{NY}$,

Data Acquisition: NÇ, NY, iHA, HŞ, FSŞ

Writting: EU, NÇ, NY, ÜA, HŞ

Critical Revision: EU, NÇ, NY, ÜA, GA

Final Approval: EU, NÇ, NY, ÜA, IHA, HŞ, FSŞ, GA

\section{REFERENCES}

1. Global Initiative for Chronic Obstructive Lung Disease (GOLD) 2020. Global Strategy for the Diagnosis, Management and Prevention of COPD. Available from: http://goldcopd.org.

2. Deslée G, Mal H, Dutau H, Bourdin A, Vergnon JM, Pison $C$, et al. lung volume reduction coil treatment vs usual care in patients with severe emphysema: the REVOLENS randomized clinical trial. JAMA 2016; 315(2): 175-84. 
3. Sciurba FC, Criner G), Strange C, Shah PL, Michaud G, Connolly TA, et al. Effect of endobronchial coils vs usual care on exercise tolerance in patients with severe emphysema: The RENEW randomized clinical trial. JAMA 2016; 315(20): 2178-89.

4. Herth JFF, Slebos D-J, Criner GJ, Shah PL. Endoscopic lung volume reduction: an expert panel recommendationupdate 2017. Respiration 2017; 94: 380-8.

5. Marchetti N, Kaufman T, Chandra D, Herth FJ, Shah PL, Slebos DJ, et al. endobronchial coils versus lung volume reduction surgery or medical therapy for treatment of advanced homogenous emphysema. Chronic Obstr Pulm Dis 2018; 5(2): 87-96.

6. Weinmann GG, Chiang YP, Sheingold S. The national emphysema treatment trial (NETT): a study in agency collaboration. Proc Am Thorac Soc 2008; 5(4): 381-4.

7. Jones PW, Carone M. Health status "quality of life." Eur Respir Mon 2000; 13: 22-35.

8. Jones PW. Health status measurement in chronic obstructive pulmonary disease. Thorax 2001; 56(11): 880-7.

9. Shah PL, Zoumot Z, Singh S, Bicknell SR, Ross ET, Quiring J, et al. Endobronchial coils for the treatment of severe emphysema with hyperinflation (RESET): a randomized controlled trial. Lancet Respir Med 2013; 1(3): 233-40.

10. Herth FJF, Slebos DJ, Criner GJ, Valipour A, Sciurba F, Shah $P L$. endoscopic lung volume reduction: an expert panel recommendation-update 2019. Respiration 2019; 97(6): 548-57.

11. van cen Berge M, Ten Hacken NHT, Cohen J, Douma WR, Postma DS. Small airway disease in asthma and COPD: clinical implications. Chest 2011; 139(2): 412-23.

12. Garner IL, Kemp SV, Srikanthan K, Caneja C, Zoumot Z, Roberts $C$, et al. 5-year survival after endobronchial coil Implantation: secondary analysis of the first randomised controlled trial, RESET. Respiration 2020; 99(2): 154-62.

13. Yildiz F. The efficacy of lung volume reduction coil treatment in patients with severe chronic obstructive pulmonary disease (COPD) type II respiratory failure. Int I Chron Obstruct Pulmon Dis 2020; 15: 479-86.

14. Bostancı K, Bilgi Z, Ömercikoğ/u H, Çetinkaya Ç, Olgun Yıldızeli Ş, Yüksel $M$, et al. Endobronchial coils in treatment of advanced emphysema: A single center experience. Turk Gogus Kalp Damar Cerrahisi Derg 2019; 27(1): 57-62.
15. Tanriverdi E, Doğan D, Turan D, Uğur Chousein EG, Yıldırım BZ, Demirkol B, et al. The impact of co-existing comorbid diseases on long-term mortality in bronchoscopic lung volume reduction. Med Glas (Zenica) 2020; 17(1): 73-8.

16. Gülsen A. Effects of bronchoscopic lung volume reduction coil treatment on arterial blood gases. I Bronchology Interv Pulmonol 2019; 26(2): 90-5.

17. Gulsen A. Importance of bronchoscopic lung volume reduction coil therapy in potential candidates for lung transplantation. Biosci Trends 2018; 12(4): 395-402.

18. Gulsen A, Sever F, Girgin P, Tamci NB, Yilmaz $H$. Evaluation of bronchoscopic lung volume reduction coil treatment results in patients with severe emphysema. Clin Respir J 2017; 11 (5): 585-92.

19. Yıldız F. Role of quantitative perfusion scintigraphy evaluation in determination of the efficiency of the procedure before lung volume reduction coil treatment for severe emphysema. Tuberk Toraks 2017; 65(2): 106-11.

20. Franke KJ, Domanski U, Schröder M, Nilius G. Effects of endobronchial coils for endoscopic lung volume reduction on sleep in COPD patients with advanced pulmonary emphysema. Sleep Breath 2020; 32845475.

21. Fellrath JM, Scherer T, Franzen DP, Lovis A, von Garnier C, Plojoux J, et al. Endobronchial coil therapy in severe emphysema: 6-month outcomes from a Swiss National Registry. J Thorac Dis 2018; 10(Suppl 23): S2711-S8.

22. Mortensen J, Berg RMG. Lung Scintigraphy in COPD. Semin Nucl Med 2019; 49 (1): 16-21.

23. Kristiansen JF, Perch M, Iversen M, Krakauer M, Mortensen J. Lobar Quantification by ventilation/perfusion SPECT/CT in patients with severe emphysema undergoing lung volume reduction with endobronchial valves. Respiration 2019; 98 (3): 230-8.

24. Chung SC, Peters MI, Chen S, Emmett L, Ing AJ. Effect of unilateral endobronchial valve insertion on pulmonary ventilation and perfusion: A pilot study. Respirology 2010; 15(7): 1079-83

25. Pizarro C, Ahmadzadehfar H, Essler M, Tuleta I, Fimmers $R$, Nickenig G, et al. Effect of Endobronchial valve therapy on pulmonary perfusion and ventilation distribution. PLOS One 2015; 10(3): e0118976. 